\title{
Beyond Epistemology: Nietzsche and the Need for Epistemic Criteria
}

\author{
ROBERT HULL \\ Missouri Western State College
}

Convictions are prisons. Nictzsche (A54)

In a recent paper, "Nictzsche's Sting And The Possibility of Cood Philology," 1 Kenneth Westphal presents a case for interpreting as strongly cognitivist a number of Nietzsche's remarks concerning truth, language and the world. The cognitivism Westphal attributes to Nietzsche is at bottom a correspondence theory of truth: that there are truths about the world that can be known and expressed, truth being a product of a correspondence between one's beliefs and the world. 2 Westphal argued in an earlier paper $^{3}$ that it is crucial to Nictzsche's enterprise that he maintain such a position, for unless he does he cannot claim to know the facts upon which he bases his stinging criticisms of the Western intellectual tradition. For example, if Nictzsche cannot claim that Christians exist or have existed, and that they possess certain intelligible psychological features, and that it is possible to know what these features are and to criticize them, then Nictzsche's own depiction of Christians as world-weary intellectually dishonest decadents is groundless. As Westphal puts it, "not interpreting him as a cognitivist-at least for a certain range of critical claims-converts the roaring lion into a noisy crank with no grasp of what's going on around him."4

Westphal believes that in order to salvage the integrity of Nictzsche's critical project by providing that project an epistemic ground attributable to Nictzsche, a formidable obstacle must be overcume, namelv Nietzsche's own skeptical remarks. As Westphal asks, "How can Nietzsche be a cognitivist given his skeptical declamations, his criticisms of language, and his perspectivism?"5 According to Westphal, a convincing case for Nietzschean cognitivism must not only provide evidence for establishing an epistemology that is cognitivist, it must also reconcile Nietzsche's skeptical remarks to this epistemology. A position that simultaneously implicd the impossibility of truth and yet advocated the

1 Kenneth Westphal, "Nietzsche's Sting and the Possibility of Cood I'hilology," International Studies in Philosophy, XVI, 71-90, 1984.

2 Ibid., p. 71.

3 Westphal, "Was Nictzsche A Cognitivist?" Journal of the llistory of Philosophy, XXII, 343-363, JI 1984.

4 Ibid., p. 353.

5 Westphal, "Niclzsche's Sting," p. 73. 
possibility of truth would be involved in a contradiction that vitiates its own usefulness as an epistemology. And, since consistency seems to be one requirement of a successful cognitivist epistemolugy, in order for Nietzsche's epistemology to function as the neressary ground of his critical project his position must be shown to be consistent. Westphal recognizes this, and indeed he maintains that his interpretation absolves Nictzsche of "epistemic inconsistency."6

Westphal is not alone in his belief that Nietzsche must be able to make truth claims and that he must provide them a ground. A number of American Nictzsche scholars have interpreted Nictzsche this way. John Wilcox writes:

Accusing your enemies of ignorance has no pnint unless you believe in the possibility and desirability of knowledge. There is no bite to the charge that someone has blinded himself to reality unless it is possible to do better-to see reality for what it is.?

Arthur Danto makes a similar point:

In the end, then, he too has his metaphysies and his theory as to what. its structure and composition ultimately must be.... There is a crucial tension throughout Nictzsche, between free-whecling critic, always prepared to shift ground in attacking metaphysics, and a metaphysical philosopher secking to provide a basis for his repudiation of any such enterprise as he is practicing. ${ }^{8}$

But an alternative to this interpretation that philosophers have failed 10 consider is that Nietzsche sought to undermine the assumption that philosophical criticism is legitimate only when it is supported by a theory or: 'stem that would provide it an epistemic sanction. In what follows 1 examine Westphal's reading of Nietzsche. After suggesting some criticisms of this reading I argue that much of Nietzsche's critique of Western philosophy is devoted to attacking assumptions that lay behind traditional epistemologies, the cognitivist position skelched above being one of them. Furthermore, I argue that the advantage of the interpretation I am proposing is that it conserves the radical character of Nietzsche's

6 lbid.. p. 74.

7 John Wilcox, Truth and Value in Nietzsche. Ann Arbor: The University of Michigan Press, 1974, p. 58.

* Arthur Danto, Nietzsche as Philosopher. New York: Columbia University l'ress, 1965, p. 80. 
critical project while squaring with and helping to make sense of his many skeptical remarks. Additionally, I suggest how this interpretation helps us to recognize that Nietzsche's philosophy does not succumb to the socalled "skeptic's paradox."

Westphal's interpretation consists in the following key claims:

(1) Nictzsche views the world as "a characterizable though highly transitory realm." 9 While the denizens of the world are in flux, this flux is not so radical that it does not have particular, intelligible characteristics.

(2) We have perceptual access to that world via the senses.t0

(3) Language is the medium of expression for representing what is made available by the senses."1

(4) The individuals capable of expressing in language what is made available by the senses are skilled philologists (identified as Ubermenschen) whose efforts are creative and cognitivist; the kind of creation Nictzsche is interested in is the creation of "a vivid, accuratc, comprehensible representation of a subject matter." 12

Nietzsche's position is coherent and consistent. In particular, his position is not undercut by a commitment to perspectivism.13

The first question that arises is, why should we believe that (1) constitutes the position Nietzsche takes regarding the nature of the world if, as Westphal admits, Nietzsche did claim that the world is "fundamentally a characterless flux"?" Westphal's argument is that the radical flux thesis is untenable and that if it was maintained by Nietzsche it would threaten his own critical project. As Westphal argues, if Nictzsche claims that the world is a characterless Heraclitean fux:

then no one, not even Nietzsche himself, could be aware of the fluctuation. Hence, he could not claim to know about it and he could not cite this as a problem for language or cognition. 15

\footnotetext{
9 Westphal, "Nietzsche's Sting," p. 75.

10 lbid., p. 76.

II Ibid., p. 77.

12 Ibiul., p. 81.

13 Ibid., p. 8.1.

14 Ibid., p. 74.

15 Ibid.
} 
Moreover, if Nietzsche did claim that all he knows about the world is that it is a characterless flux:

then he would put himself in the position for which he derides Kant, namely, of knowing just enough about reality to know that it is unknowable. ${ }^{16}$

The conclusion Westphal draws is that we must accept "a Nietzschean middle course between sheer chaotic flux and pure Being." 17

Do we have pereeptual access to the world of (1) via the senses, according to Nietzsche? Westphal draws on several passages to show that Nietzsche's answer is yes, we do:

\begin{abstract}
All credibility, all good lintellectuall conscience, all evidence of truth comes only from the senses (BCE 134). (The senses) lie neither in the way the Eleatics believed, nor as [Heraclitus] believed-they do not lic at all. What we make of their testimony, that alone introduces lies.... "Reason" is the cause of our falsification of the testimony of the senses (GM III 2).
\end{abstract}

This is a crucial part of Westphal's case because according to his interpretation Nietzsche spurns transcendent metaphysics while embracing empiricism. It is this empiricism, evidenced by the above citations, that allows Nictzsche the recognition that the world is a moderate flux while providing him the facts upon which his critique of philosophy, religion and art is based. These passages indicate that "there is at least room for perceptual access to an empirical realm according to the late Nietzsche."18 Taken together these passages lead Westphal to conclude that in his mature efforts Nictzsche absolves the senses of bias, thereby allowing them to function as the inlets of veracious information concerning the world.

But we cannot establish that Nictzsche held a correspondence theory of truth solely by pointing out his confidence in the senses, for the information they provide can be uscful in this regard only if there is some means by which this information can be utilized. Surprisingly, Westphal identifies language as the means by which Nietzsche believed it possible to make use of the data of sensation:

Is language capable of expressing or representing what is made available by the senses? Against all interpreters

\footnotetext{
16 Ibid., p. 75.

17 lbid., p. 84.

18 Ibid., p. 76. But see CS 372 and BCE 192 for a different perspective on the testimony of the senses.
} 
who have foundered on the problem of language in Nietrsche, it must be noted that in fact Nietzsche did think it possible to 'speak straight to all things.'19

Westphal argues that Ubermenschen, whom he identifies as skilled philologists of the future, will in Nietzsche's opinion overcome the dissimulative tendencies of ordinary language and thus become adept at describing the empirical realm. That Nietzsche considered language to be a possible means of reliable expression is evidenced, in Westphal's view, by the following passages taken from Zarathustra:

Here all things come caressingly to your discourse and flatter you .... On every parable you ride to every truth.

Here you may talk fairly and frankly to all things: and verily, it rings in their ears like praise when somebody talks straight to all things.

Here the words and word-shrines of all being open up before me: here all being wishes to become word, all becoming wishes to learn from me how to speak (Z. III, Return Home).

This point is being stressed again in the following passage "in more conceptual, epistemological terms," according to Westphal:

In a dream, in the last dream of the morning, I stood in the foothills today-beyond the world, held scales, and weighed the world ....

Measurable by him who has time, weighable by a good weigher, reachable by strong wings; guessable by divine nutcrackers: thus my dream found the world.

How surely my dream looked upon this finite world, not inquisitively, not acquisitively, not afraid, not begging, as if a full apple offered itself to my hand ... as if delicate hands carried a shrine toward me, a shrine open for the delight of bashful, adoring eyes, thus the world offered itself to me today; not riddle enough to frighten away human love, not solution enough to put to sleep human wisdom: a humanly good thing the world was to me today, though one speaks so much evil of it ( $Z$ III, Three Evils).

19 Ifisd., p. 77. 
Finally, Westphal believes that the possibility of eliminating linguistic inadequacy is indicated in the following passage, where: Zarathustra says

I flew ... away into distant futures which no dream had yet seen, into hotter souths than artists ever dreamed of, where gods in their dances are ashamed of all clothes--to speak in parables and to limp and stammer like poets; and, verily, I am ashamed that I must still be a poet (Z III, Tablets 2).

The type of truth Westphal thinks the Übermenschen will be capable of creating will be "a vivid, accurate, comprehensible representation of the main fealures of a subject matter." 20 Yet this will be a somewhat openended or perspectival representation, for there can be different perspectives on a given subject, depending on which features are represented. As Westphal argues,

Cognitivism does not require complete knowledge of an object. Though Nictzsche's perspectivism is cognitivist, this does not mean that there is any single, completely correct, "beatific" interpretation of anything. Kather, the point of view involved in perspectival cognition scems to entail a radical incompleteness and, due to this, and open-ended revisability of interpretations. 21

Westphal goes on to suggest that the cognitive strength of a particular perspective derives from the employment of varieties of perspectives used to view a given subject matter, and this strength amounts to a limited objectivity. Nietzsche's philologist, while capable of grasping and communicating how things are, does not do so omnisciently. As one can see, Westphal is attempting, very cleverly I might add, to locate Nictzsche's perspectivism within the context of a cognitivism that is epistemically strong enough to vouchsafe the integrity of both that perspectivism and his critique of Western philosophy, religion and culture. That this is the notion of objectivity that is recommended by Nietzsche, and that this notion is consistent with Nietzsche's perspectivism is substantiated by the following quotation:

There is only a perspective secing, only a perspective "knowing"; and the more affects we allow to speak about one thing, the more cyes, and different eyes, we can use to

20 lbid., p. 81.

21 Ibid. 
observe une thing, the more complete will our "concept" of this thing, our "objectivity," be (CM III 12).

At this point I would like to suggest some criticisms of the case West phal makes for reading Nictzsche as a cognitivist, beginning with his argument for (1), the "moderate flux" thesis. His argument, at least as I understand it, is simply that without an epistemic foundation Nietzsche's critical project must come crashing down and that (1) would be a necessary component of that foundation. But this does not establish that Nictzsche was committed to (1). On the contrary, the most that Westphal can have shown is that Nictzsche's position requires something like (1), and not that it actually includes it. That the coherence of Nietzsche's views demands a particular claim would not be sufficient evidence for attributing that claim to Nietzsche. It might be the case, after all, that Nietzsche is involved in a fundamental inconsistency. And since one of Westphal's goals is to absolve Nictzsche of epistemic inconsistency, the threat of this cannot be taken as evidence for attributing to him any determinate position. What would be helpful is textual evidence that establishes Nietzsche's commitment to (1), but I am unaware of any passages in which Nietzsche suggests that the world is 'a characterizable though highly transitory realm.' But even if one were to find a passage of this kind, one might still be at a loss to account for those where Nietzsche is apparently committed to the radical fux thesis.

Furthermore, the passages from Zarathustra that Westphal cites cannot be interpreted as evidence suggesting Nietzsche's belief in the possibility and desirability of veracious, non-metaphorical referential language. The first one ('on every parable you ride to every truth') is viewed by Westphal as an expression of Nietzsche's belief that it is possible to 'speak straight to things,' i.e. that language will be capable of representing adequately the testimony of the senses. The third passage $\mathrm{L}$ taken to indicate that this possibility will be actualized in a distant future imagined by Zarathustra, who laments $I$ am ashamed that I must still be a poct' because (on Westphal's view) of Zarathustra's own reliance on metaphorical language. But in the first passage Zarathustra's solitude serems to claim not only the possibility of veracious language, but the actuality as well. It appears to indicate the possession of this facility. In any event the use of parabolic language is praised, for it is on parables that Zarathustra 'rides to every truth.' Later, in Ecce Ilomo, Nictzsche refers to this passage:

The involuntary nature of image, of metaphor is the most remarkable thing of all; one no longer has any idea what is image, what metaphor, everything presents itself as the readiest, the truest, the simplest means of expression. It really does seem to allude to a saying of Zarathustra's, 
as if the things themselves approached and offered themselves as metaphors (here all things come caressingly to your discourse and fatter you . . .) (E II Zaralhustra 3)

Instead of lamenting the awkward and ineffectual character of metaphorical expression, as one would expect given Westphal's interpretation, Nictzsche is apparently celebrating the inspiration that has given rise to that sort of expression. And while these lines cannot be understood properly until one comes to terms with what is meant by the truest, the simplest means of expression, prima facie they seem inconsistent with the belief that Nietzsche viewed tropolngical language as inherently flawed and inevitably futile and that he longed for the nonmetaphorical expression of experience.

Without appropriate epistemic support, Westphal claims, Nietzsche's criticisms are groundless, and his otherwise insightful critiques become little more than the shrill ravings of an ill-tempered crank. However, I believe that at least part of what makes Nictysche's thought genuinely revolutionary is his questioning of the need for, the possibility of, and the motivation behind the very sort of epistemic ground that Westphal sees as an indispensable element of Nietysche's philosophy. To put the matter a little differently, what Westphal's interpretation misses is Nietzsche's multivalent attack on the role that truth has traditionally been assigned within philosophy.

Why should we think that the value of Nietzsche's critical project hinges on whether an epistemic ground is available for it? To claim that the usefulness or the appropriateness of philosophical thought is ultimatcly determined by the availability of such a ground is to make an assumption that Nietzsche wanted to question. For in a number of passages located in his mature works Nictzsche proposes to question the faith all philosophers have shared in the value of truth. This is part of what I would call Nictzsche's critique of epistemology, a critique that consists in a collection of suggestions that challenge the idea of a philosopher as an individual who knows in advance of practice what values and drives motivate that practice, and who knows the propricty of those values and drives and what ends they ought to serve. An example of this critique can be found at the beginning of Beyond Good And Evil, where Nietzsche writes:

The will to truth which will still tempt us to many a venture, that famous truthfulness of which all philosophers have spoken with respect--what questions has this will to truth not laid before us! What strange, wicked, questionable questions! That is a long story even now-and yct it scems as if it had scarcely begun. Is it any 
wonder that we should finally become suspicious, lose patience, and turn away impatiently? that we should finally learn from this Sphinx to ask questions, too? Who is it really that puts questions to us here? What in us really wants "truth"?

Indeed we came to a long halt at the question about the cause of this will--until we finally came to a complete stop before a still more basic question. We asked about the value of this will. Suppose we want truth: why not rather untruth? and uncertainty? even ignorance? (BGE 1; \&. BCE 34).

When confronted with the above quotation Westphal's reaction might be to insist that Nictzsche has in mind here philosophers who indulge in Iranscendent metaphysics and who would, unlike Übermenschen, insist on the absolute truth of their (in actuality) other-worldly metaphysical theories. But it does not seem obvious to me that these questions would be limited in this way, and that they could not be asked of those whose project would be the creation of "a vivid, accurate, comprehensible representation of the main features of a subject matter." After all, supposing that for Nietzsche truth of this kind is possible, couldn't we ask: why shouldn't we prefer untruth, uncertainty, or even ignorance? This question seems appropriate if only because Nictzsche wants to undermine the unquestioned importance philosophers have ascribed to the project of attaining a clear understanding of things. This is what he is doing in the following passage, one that recalls his enthusiasm for ambiguity, enigma and mystery:

A matter that becomes clear ceases to concern us.-What was on the mind of that god who counseled: "Know thyself?" Did he mean: "Cease to concern yourself! Become objective!"-And Socrates? And "scientific men"? (BCE 80; cf. GS 357).

That Nictzsche questioned the value that has been placed on truth by all philosophers, and that he seemed pessimistic that this value could find any justification is further evidenced by the following passage, taken from The Genealogy of Morals:

Here let us pause and take thought. It appears that today incuiry IWissenschaftI itself stands in need of justification (by which I do not mean to say that such justilication can be found). In this connection let us glance at both the oldest and the most recent philosophers: 10 a man they lack all awareness that the will to truth itself 
needs to be justificd. There is a gap here in every philosophy-how are we to explain it? By the fact that the ascetic ideal has so far governed all philosophy; that truth was premised as Being, as Cod, as supreme sanction; that truth was not allowed to be called into question. But once we withhold our faith from the god of the ascetic ideal a new problem poses itself, the problem of the value of truth. The will to truth must be scrutinized; our business now is tentatively to question the will to truth (GM III 24).

A passage like this one is challenging in a number of ways. First it may be asked what sort of "truth" Nietzsche has in mind here. I'resumably commentators who feel it necessary to attribute to Nietzsche some substantive theoretical claims concerning knowledge would endeavor to restrict the sense of truth in passages like this one to that of metaphysical truth, i.e. truth of the sort to which philosophers like Parmenides, Plato and Descartes aspired. But that Nictzsche is not restricting his criticism to philosophers who attempt to construct ambitious metaphysical theories, and that it does apply to any philosopher who has assumed iruth's unparalleled value, whether empirical or otherwise, is borne out by the inclusiveness of the above passage ("the oldest and most recent philosophers: to a man ....) and by the inclusion of atheists and antimetaphysicians in his criticism of the unreflective acceptance of the ascetic ideal in the lines direclly preceding this quotation.22

But if his critique is unrestricted in this manner a second problem arises: How could Nietzsche be questioning so comprehensively the role of truth in philosophy? For if he is suggesting that the will to truth be scratinized he must be interested in understanding the role of truth in philosophy, and that means he is interested in getting something right

22 "These proud solitaries, absolutely intransigent in their insistence on intellectual precision, these hard, strict, continent, heroic minds, all these wan atheists, Antichrists, immoralists, nihilists, sceptics, suspenders of judgment, embodying whatever remained of intellectual conscience todayare they really as free from the ascetic ideal as they imagine themselves to be? I would tell them something which they cannot sce because they are 100 close to themselves: it is they, preciscly, who today represent the ascetic ideal; it is they who are its most subtle exponents, its scouts and advance guard, its most dangerous and elusive temptation .... These men are a long way from being free spirits, because they still belicve in truth ... " (CM III 24; See also BCE 3 and CS 347). It is difficult to see how this passage could be interpreted as being concerned with only one notion of truth, e.g. metaphysical truth. The word translated above as "truth" is Wahrheil. 
about philosophy. And, wouldn't this locate him within the very tradition he intends to challenge?

This is the "skeptic's paradox" I mentioned earlicr. It is meant to compromise Nietzsche's thought by showing him to be making unfairly an exception in his own case. It can be answered by pointing out that taking an interest in the role of truth in philosophy, and indeed wanting to know the justification accorded it and doubting whether any justification can be found can be done without contradiction. All that Nietzsche need avoid is placing the value on truth that he presumably wants to challenge. What this means is that Nietzsche must avoid philosophizing in such a way that he makes truth a necessary or final arbiter within his own philosophy. This would include refraining from assenting to the need for an epistemic or metaphysical ground for his philosophy. This would be contradictory, for it would locate him squarely within the tradition that he finds at bottom gratuitous.

This leads to a third difficulty, and it is one that is related to Westphal's problematic: how can Nictzsche attack Western philosophy and the value it has placed on truth without making truth claims that would compromise the integrity of his attack? That is, how is it possible for Nietzsche to question the goals and assumptions of an epistemology that is for example within the Cartesian tradition without employing a rival notion of truth that would have enough epistemic muscle to present a formidable challenge to an epistemology of this kind? And if Nietzsche's attack did rely on and draw strength from an alternative conception of truth then he would be susceptible to the very objection that he raises against all the philosophers who have followed in the ascetic tradition, viz. making truth the ultimate sanction in philosophy.

I think that this line of questioning, which has received a fair amount of attention in recent Nietzsche scholarship, involves a misunderstanding of Nietzsche's attitude toward theories of knowledge. In particular, it assumes that for Nictzsche, as well as for anybody, epistemology must be philosophically primitive. I say this because its chief assumption is that a theory of knowledge can only be challenged by a rival theory. It assumes that epistemology, or any other philosophical perspective, can only be assailed by an argument that commits itself at some level to beliefs about the nature of truth and knowledge. But this assumption makes an unfair demand on Nietzsche while missing the revolutionary character of his thought, for Nictzsche questions not only the viability of epistemology but its authority and usefulness as well.

Consider the following quotation in which Nietzsche criticizes matcrialistic natural scientists, a criticism that, it seems to me, would apply to the projert Westphal has in mind for Nictzsche's Übermenschen: "Above all, one should not wish to divest existence of its rich ambiguity: that is a dictate of good taste, gentlemen, the taste for reverence for everything that lies beyond your horizon." (C.S 373) In this quotation 
Nictzsche is criticizing a form of world interpretation that while different from the one altributed by Westphal to Nietzsche's Übermenschen is alst) empirically oriented. His criticism is motivated by standards that are not, so to speak, immanent to those one would normally assiciate with projects whose goal is a clear, accurate portrayal of the world. As is typical of this type of criticism, a project is atlacked from a perspective that is foreign 10 it, from one that does not take truth as the only or the ultimate standard. Specifically. what Nietzsche is questioning is whether the natural scientists' efforts emanate from a reverential allitude loward existence. And part of the motivation bchind this kind of critique is to get us to rethink our philosophical priorities, one of which is the often claimed but seldom justified priority placed on truth.

The following quotation is another example of what I would call Nietzsche's moral critique of truth in philosophy. Having defined the will to truth as the will not to deceive or be dereived. Nictzsche gexes on to write:

One does not want to allow oneself to be deceived because one assumes that it is harmful, dangerous, calamitous to be deceived. In this sense, science would be a long-range prudence, a caution, a utility; but one can object in all fairness: How is that? Is wanting not to allow oneself to be deceived really less harmful, less dangerous, less calamitous? What do you know in advance of the character of existence to be able to decide whether the greater advantage is on the side of the unconditionally mistrustful or of the unconditionally trusting? (CS 344).

In this passage Nictzsche is contesting one of the more widespread presuppositions that has influenced the manner in which philosophers have understood questions concerning knowledge and reality. This is the view that such questions ought to be raised independently of any other concerns, or that any competing concerns are already recognized along with their relation to epistemology. Philosophers have believed themselves to possess, in advance of investigation, an understanding of the proper hicrarchy of speculation, positing as most fundamental questions concerning the nature of truth. The problem of objectivity is seen as arising only after the initial epistemic act, only after the question "what is truth?" has been raised, and it then becomes a matter of safeguarding against influences that would usurp the authority of this question or that would contaminate attempts at providing it an answer. Thus the question "what is Iruth?" is understoxd as one that can only be approached in a vacuum, so to speak, or in an environment cleansed of whatever might be alien to or in defiance of llic authority of this question. Westphal's interpretation of Nictzsche's 
philosophy is one that is committed to this view of the hicrarchy of philosophical speculation.

There emerges along with this a view of the philosopher who is seen as an individual in whom whatever passions, attachments or interests that might be antagonistic towards the pursuit of truth have been vanquished. Generally. Nietzsche considers the traditional conception of the philosopher to be dominated by an ascetic ideal in which the needs for certainty, clarity and a foundation for beliefs are unquestioned. The "objectivity" presumed by philosophers has led them to view the valuations that comprise this ideal-clarity, coherence, fidelity to fact and freedom from deception, to name a few--as requirements of their practice instead of as assumptions whose merits may be called into question. Thus the ascetic ideal and the faith in the autonomy and primacy of traditional epistemology have proven to be obstacles to speculation rather than its necessary assumptions and components. That is to say, Nietzsche views the objectivity claimed by philosophers to have been an immense prejudice that would require, and should not be assumed to determine, the nature of philosophical justification. But as we have seen, this does not mean that he was at all optimistic that a justification could be given.

Nietzsche criticizes the epistemic constituent of the ascetic ideal by using its own standards to reveal that the demand for a ground is groundless or that the requirement of certainty is an uncertain one. He is, one might say, simply giving that which is falling a push. In this respect part of his critique of epistemology is carried on within the domain of epistemology. But this is not the case with other aspects of his critique, most notably his speculations concerning the origin and development of our faith in and our need for explanation, knowledge and for convictions that we can be assured are true. This investigation is carried out beyond or outside of the domain of theory of knowledge, and it contains many of the critical "stings" that, if Westphal were right, would require an epistemic ground so that they could be known to be true. But it is precisely this need that Nietzsche is questioning:

Look, isn't our need for knowledge precisely this need for the familiar, the will to uncover under everything strange, unusual, and questionable something that no longer disturbs us? Is it not the instinct of fear that bids us to know? And is the jubilation of those who attain knowledge not the jubilation over the restoration of a sense of security? (C.S 355).

The demand for certainty is likewise questioned in the following passage: 
Metaphysics is still needed by some; but so is that impetuous demand for certainty that today discharges itself among large numbers of people in a scientificpositivistic form. The demand that one wants by all means that something should be firm (while on account of the ardor of this demand one is easier and more negligent about the demonstration of this certainty)--this, toos, is still the demand for a support, a prop, in short, that instinct of weakness which, to be sure, does not creatc religious, metaphysical systems, and convictions of all kinds but-conserves them (CS 347).

Passages like this one, in which the need for secured convictions is questioncd, can be found in all of Nietzsche's mature works.23 To ask whether they are true or whether there is an epistemic ground available for them is itself a misunderstanding of them, for it is this need that Nictzsche questions. And if, as I have argued, Nietzsche's philosophy is beyond traditional epistemology, attempts at providing his criticisms of Western religion, philosophy and culture a theoretical base that reflects the standards of traditions he found questionable is to miss one of the most radical aspects of his thought.

Finally, I should point out that none of this is opposed to Nictzsche's view of himself as a lover of knowledge or as a friend of truth. This may be understood as an expression of confidence in his own intellectual integrity and honesty. Possessing an intellectual conscience is for Nietzsche a malter of resisting the various fcars, passions, weaknesses and desires that may tempt a philosopher to find gratification or take refuge in convictions or systems of belicf.24 This requires, among other things, courage, hardness and cruclly towards oneself, the ability to view something from a variety of perspectives while not remaining in one perspective, and perhaps above all strength and freedom of spirit. Perhaps one must be like Zarathustra, wh.om Nietzsche said "is more truthful than any other thinker."25 But of Zarathustra Nictzsche also wrote the following:

One should not let oneself be misled: great intelleets are sceptics. Zarathustra is a sceptic. The vigor of mind, its freedom through strength and superior strength, is proved by scepticism. Men of conviction simply do not come into consideration where the fundamentals of value and

23 For example, sce Twilight of the Idols, "The Four Creat Errors" 5 , "Expeditions of an Untimely Man," 26; CS 370; A 55.

24 "The will to a system is a lack of integrity," TI "Maxims and Arrows," 26.

25 EH "Why I Am A Destiny," 3. 
disvalue are concerned. Convictions are prisons. They do not seve far enough, they do not sere things beneath them: but to be permilted t(t) speak about value and disvalue one must sere five hundred convictions beneath one-behind one .... A spirit which wants to do great things, which also wills the means for it, is necessarily a sceptic. Fricudom from convictions of any kind, the capacity for an unconstrained view, pertains to strength.... (A 54).

\section{Abbreviations/Texts}

A The Anti-Christ, trans. R. J. Hollingdale (New York: Penguin Books, 1984).

BCE Beyond Cood and Evil, trans. Walter Kaufmann (New York: Vintage Books, 1955).

EH Ecce Hlomo, trans. R. J. Hollingdale (New York, Penguin Books, 1980).

OM On the Genealogy of Morals, trans. Francis Colffing (Garden City, New York: Doubleday, 1956).

OS The Gay Science, trans. Walter Kaufmann (New York: Vintage Books, 1974).

II Twilight of the Idols, trans. R. J. Hollingdale (New York: Penguin Books, 1984).

WP The Will to Power, trans. Walter Kaufmann and R. J. Hollingdale (New York: Random House, 1967).

Z Thus Spoke Zarathustra, trans. Walter Kaufmann (New York: Penguin Books, 1985). 